\title{
Rational parameters of the transportless technological scheme for the development of strata with maximum permissible dip angle
}

\author{
Tatiana Gvozdkova ${ }^{1, *}$, and Manuela Koščova ${ }^{2}$ \\ ${ }^{1}$ Mezhdurechensk Branch of T.F. Gorbachev Kuzbass State Technical University, 652877 \\ Mezhdurechensk, 36 Stroitelei av., Russian Federation \\ ${ }^{2}$ Mathematical Institute, Slovak Academy of Sciences, 81473 Bratislava, Stefanikova \\ $898 / 49$, Slovakia
}

\begin{abstract}
In this article the rational value of overburden cut width and thickness of transportless overburden at mining of two dispersed flat seams IV-V and VI at Kureinsky section of Sibirginsky open pit mine are presented, which makes it possible to minimize the volume of rock reexcavation under the condition of the planned annual productivity of coal on the open pit and to ensure reduction of stripping costs. This task is complicated by the fact that the dip angle at the section is close to the limit on the condition of the possibility of spoiling of internal dump, and since the overburden rocks of the section are represented mainly by large-block sandstones on the clay cement and siltstones and their compressive strength is $60-80 \mathrm{MPa}$, then it is required to use a drilling and blasting method of their preparation for excavation. Under such conditions, optimizing the parameters of the transportless excavation scheme is of special importance for effective mining of the section.
\end{abstract}

\section{Mining and geological conditions of site}

At the Kureinsky section of Sibirginsky open pit mine (a branch of Southern Kuzbass OJSC), a strata of three flat coal seams III, IV-V and VI is developed according to the mixed deepening and continuous mining system. Angle of occurrence of seams is $14 \div 17^{\circ}$, being on average $15^{\circ}$. The thickness of seams IV-V and VI parting is $14 \mathrm{~m}$, the thickness of seams III and IV-V parting is $35 \mathrm{~m}$. The maximum thickness of transportless overburden $\left(\mathrm{H}_{\mathrm{dd}}\right)$ can reach up to $49 \mathrm{~m}$. The upper seam III, with a thickness of $7.2 \mathrm{~m}$, is mined by transport technology. Two lower dispersed seams IV-V and VI are mined by direct dumping technology with draglines ESH 20.90. The lower seam VI has an average thickness of $4.5 \mathrm{~m}$, and the overlying seam IV-V has a thickness of $8.5 \mathrm{~m}$.

At the site, in order to improve the performance of the transportless technology on an experimental basis was increased to a width of 60 meters (according to the project of "Sibgiproshakht" project bureau it was $40 \mathrm{~m}$ ). However, the desired result was not

\footnotetext{
* Corresponding author: gvozdkovatn@kuzstu.ru
} 
obtained. By order of Southern Kuzbass OJSC the following problems were solved: the rational value of width of overburden strip when using dragline ESH 20.90 and the total height of transportless overburden were defined.

To solve them the variants of excavation schemes with different height of transportless overburden $\left(\mathrm{H}_{\mathrm{dd}}\right)$ and the width of overburden strip $\left(\mathrm{W}_{\mathrm{s}}\right)$ were considered.

\section{Materials}

When estimating the dump side properties of the excavation scheme, the linear parameters of the tiers and the capacity of the entire dump were calculated. The calculations were based on the method described in [6-12].

As the amount of the re-excavating rock significantly depends on the number of the internal dump tiers, their number was defined for each variant proceeding from the comparison of the volume of the overburden bench (for $1 \mathrm{~m}$ of the mining front) and the capacity of the internal dump (tab.).

Table. Dump capacity and tiers number

\begin{tabular}{|c|c|c|c|c|c|}
\hline \multirow[t]{2}{*}{ Indicators } & \multirow{2}{*}{$\begin{array}{c}\text { Width of } \\
\text { strip }\left(\mathbf{W}_{\mathrm{s}}\right), \mathbf{m}\end{array}$} & \multicolumn{4}{|c|}{$\begin{array}{l}\text { Height of direct dumping } \\
\text { overburden }\left(H_{d d}\right), m\end{array}$} \\
\hline & & 34 & 39 & 44 & 49 \\
\hline \multirow{5}{*}{$\begin{array}{l}\text { Volume of rock in overburden bench per } \\
1 \mathrm{~m} \text { of mining front (in loosened form), } \\
\mathrm{m}^{3}\end{array}$} & 40 & 2009 & 2289 & 2559 & 2849 \\
\hline & 45 & 2247 & 2562 & 2877 & 3192 \\
\hline & 50 & 2485 & 2835 & 3185 & 3535 \\
\hline & 55 & 2723 & 3108 & 3493 & 3878 \\
\hline & 60 & 2961 & 3381 & 3801 & 4221 \\
\hline \multirow{5}{*}{$\begin{array}{l}\text { Dump capacity per } 1 \mathrm{~m} \text { of mining front, } \\
\mathrm{m}^{3}\end{array}$} & 40 & \multicolumn{4}{|c|}{2412} \\
\hline & 45 & \multicolumn{4}{|c|}{2778} \\
\hline & 50 & \multicolumn{4}{|c|}{3144} \\
\hline & 55 & \multicolumn{4}{|c|}{3406} \\
\hline & 60 & \multicolumn{4}{|c|}{3669} \\
\hline \multirow{5}{*}{ Number of internal dump tiers } & 40 & & & \multicolumn{2}{|c|}{4} \\
\hline & 45 & \multicolumn{2}{|c|}{3} & \multicolumn{2}{|c|}{4} \\
\hline & 50 & \multicolumn{2}{|c|}{3} & \multicolumn{2}{|c|}{4} \\
\hline & 55 & \multicolumn{2}{|c|}{3} & \multicolumn{2}{|c|}{4} \\
\hline & 60 & \multicolumn{2}{|c|}{3} & \multicolumn{2}{|c|}{4} \\
\hline
\end{tabular}

As can be seen from Table, because of the significant angle of bedding (on average $15^{\circ}$ ), i.e., the maximum possible for internal dumping without the use of special anti-slide measures, it is necessary to fill three- and four-tier dumps. This circumstance predetermines a high re-excavation ratio.

\section{Results}

For each variant, parameters were calculated and excavation scheme was plotted. An example of the excavation scheme for $\mathrm{H}_{\mathrm{dd}}=49 \mathrm{~m}$ and $\mathrm{W}_{\mathrm{s}}=40 \mathrm{~m}$ is shown in Fig. 1-a, $\mathrm{b}$.

Calculations of drilling and blasting parameters were carried out according to the method $[1-5,13-23]$ with a specific explosive rate of $1 \mathrm{~kg} / \mathrm{m}^{3}$, inclined drilling of boreholes at an angle of $75^{\circ}$, a grid of boreholes $6 \times 7 \mathrm{~m}$. The volume of explosive dropping of rock directly into the dumping layer is insignificant (not more than 2-3\%). Parameters of the internal dump are accepted as follows: the height of the first tier is equal to $30 \mathrm{~m}$ (on the recommendations of the Siberian branch of VNIMI institute) at an angle of its cutting is $40^{\circ}$ 
(Fig. 1-b), the general angle of slope is $29^{\circ}$ (Fig. 1-b), the loosening of rocks ratio in the dump is 1.4. Angle of natural slope of the second tier is $37^{\circ}$ (Fig. 1-b).

When plotting excavation schemes, the presence of a road in the base of the dump, which is filled in during the formation of the dump, is taken into account.

Volumes of re-excavation in the schemes with backfilling three-tiered dumps are: the route of the dragline working stroke $\mathrm{S}_{\text {routel }}$, created when preparing a capacity in the second tier (Fig. 10-13-14-11 in Fig. 1-a); the volume of rocks extracted from the previously filled dump during preparation of capacity in the second tier $\mathrm{S}_{\text {re.3 }}$ (Fig. 9-10-11-12); the route of the dragline working stroke $S_{\text {route2 }}$ when excavating a bench between seams III and IV-V (Fig. 1-2-3 in Fig. 1 a); the route of the dragline working stroke $S_{\text {route3 }}$ created when reloading the temporary spoil (Figs. 4-5-17-16-7) into the second tier (Fig. 6-8-15-17); the route of the dragline working stroke $\mathrm{S}_{\text {route4, }}$, created for excavation of parting between seams IV-V and VI (Fig. 1-2-3-4 in Fig. 1b); volume of temporary spoil $\left(\mathrm{S}_{\mathrm{ts}}\right)$ (Fig. 4-5-17-16).

When backfilling four-tier internal dumps, to the listed volumes of re-excavation are added: two volumes of rock moved into the fourth tier; the route of the dragline working stroke when moving the rock from the third to the fourth tier.

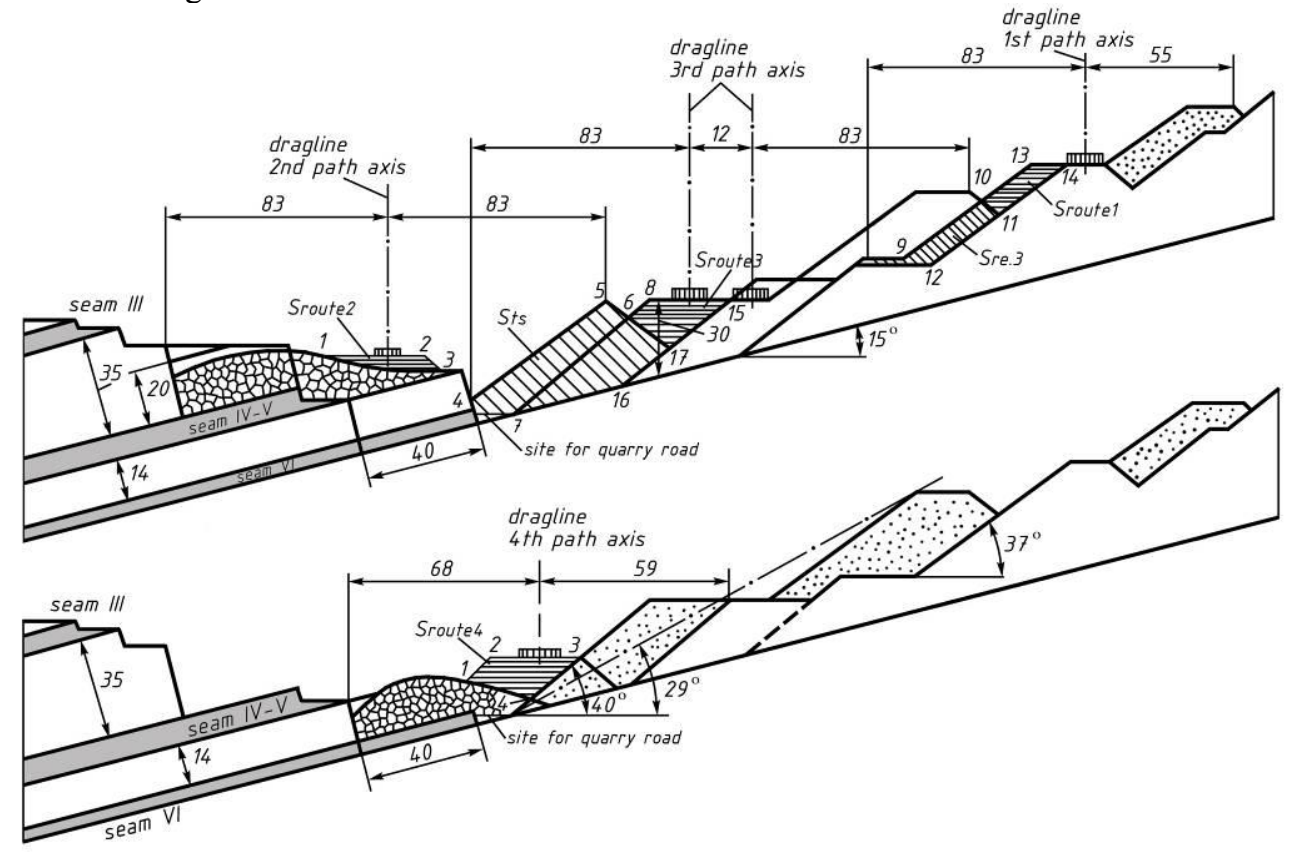

Fig. 1. Scheme of excavation for direct dumping mining of the strata of two dispersed seams in the site "Kureinsky": a - mining of the overburden bench in the parting of seams III and IV-V; $b$ - mining of the parting of seams IV-V and VI.

The re-excavation ratio in the mining profile $\mathrm{K}_{\mathrm{re}}$ is calculated by the following formula:

$$
K_{r e}=\frac{\sum S_{r e}}{\left(H_{1}+H_{2}\right) \cdot W_{s} \cdot K_{l}},
$$

where $\Sigma \mathrm{S}_{\mathrm{re}}$ is the sum of rock volumes of all re-excavated elements, $\mathrm{m}^{3} ; \mathrm{H}_{1}$ is the thickness of parting of seams IV-V and VI, $\mathrm{m} ; \mathrm{H}_{2}$ is the height of transportless overburden bench over seam IV-V, $\mathrm{m} ; \mathrm{K}_{\mathrm{l}}=1.4$ is the loosening factor of rock in the dump.

Dependences of $K_{\text {re }}$ ratio on the height of transportless overburden $\mathrm{H}_{\mathrm{dd}}$ and the width of the strip $\mathrm{W}_{\mathrm{s}}$ were obtained (Fig. 2-a, b). 
The ratio $K_{\mathrm{re}}$ changes as parabolic dependence from the height of transportless overburden $\mathrm{H}_{\mathrm{dd}}$. This can be explained by the fact that with the increase of $\mathrm{H}_{\mathrm{dd}}$ there is a transition from three-tier dumping to four-tier dumping and therefore the volume of re-excavation increases. The intensity of the increase in $\mathrm{K}_{\mathrm{re}}$ with the increase in $\mathrm{H}_{\mathrm{dd}}$ is very high: 0.025 0.043 per one meter increase in the height of overburden strata.

The coefficient $K_{\text {re }}$ linearly increases with increasing the width of the strip $W_{s}$. This is explained by the fact that the volumes of re-excavation elements increase linearly: $S_{t s}$, $\mathrm{S}_{\text {route1, }} \mathrm{S}_{\text {route2, }} \mathrm{S}_{\text {route3 }}, \mathrm{S}_{\text {re.3. }}$.

As a whole it should be noted, that because of the significant angle of dip, re-excavation ratio has the big value, even at minimum height of transportless overburden $\mathrm{H}_{\mathrm{dd}}=34 \mathrm{~m}$ and width of strip $\mathrm{W}_{\mathrm{s}}=40 \mathrm{~m}\left(\mathrm{~K}_{\mathrm{re}}=1.01\right)$ and sharply increases with increase of transportless overburden height to the values $1.40-1.70$, i.e. to the values close to maximum allowable under economic conditions $[13,14]$.
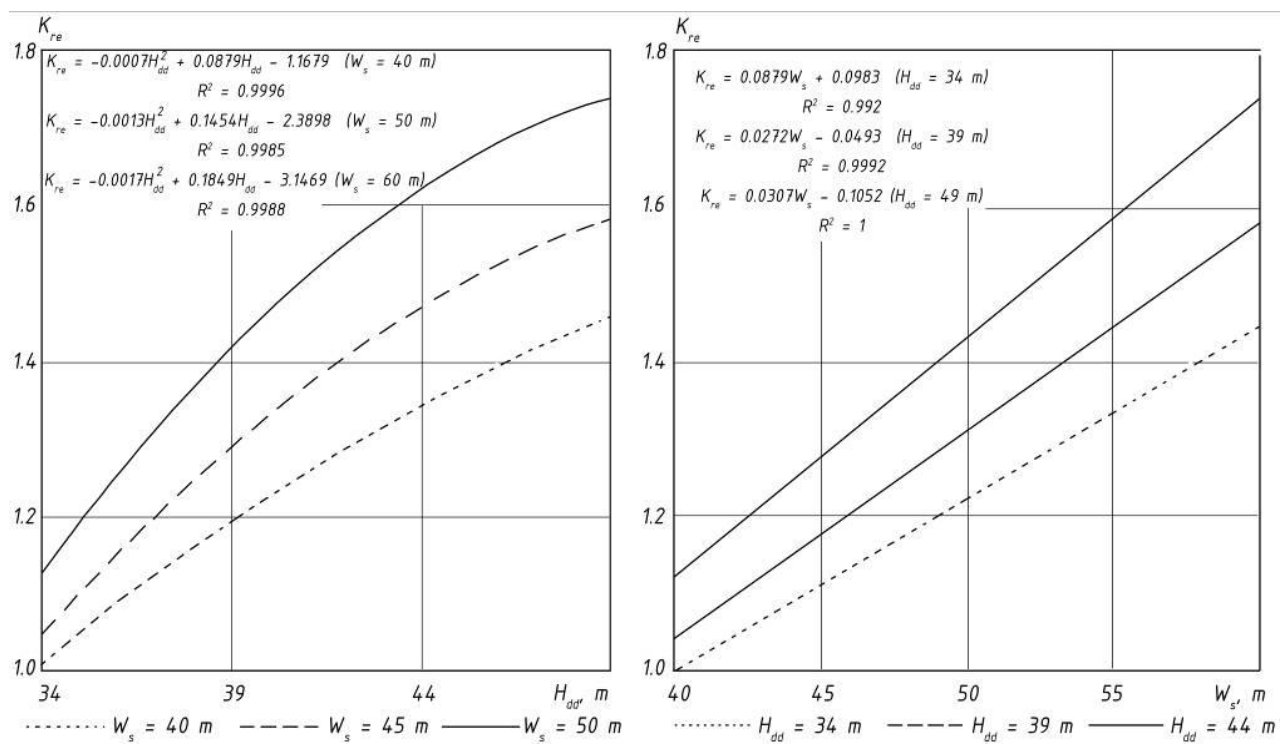

Fig. 2. Dependences of re-excavation ratio $K_{r e}$ on: $a$ - the height of the transportless overburden $\left(\mathrm{H}_{\mathrm{dd}}\right) ; \mathrm{b}$ - the width of the strip $\left(\mathrm{W}_{\mathrm{s}}\right)$.

The functions $\mathrm{K}_{\mathrm{re}}=\mathrm{f}\left(\mathrm{H}_{\mathrm{dd}}\right)$ and $\mathrm{K}_{\mathrm{re}}=\mathrm{f}\left(\mathrm{W}_{\mathrm{s}}\right)$ do not have an optimum within the studied limits, so to determine the rational values of the parameters $\mathrm{H}_{\mathrm{dd}}$ and $\mathrm{W}_{\mathrm{s}}$ a restriction is necessary. The condition of fulfilling the annual coal output plan at the site was taken as a restriction. On the basis of the plotting of planograms for each option of the equipment (drilling, excavation-loading on the transport benches, re-handling on the transportless benches and winning) determined the time of excavation of the strip, the rate of mining front of work moving and the annual volume of coal output $\left(\mathrm{O}_{\mathrm{a}}\right)$. The parameters were calculated on the basis of the following data: the length of the mining front of 750 meters; the planned coal losses on seams IV-V and VI $-12.56 \%$; on seam III $-9,7 \%$; the annual capacity of rope shovels EKG-12.5 equal to 1900 thousand $\mathrm{m}^{3}$; distance of rock transportation - $3.6 \mathrm{~km}$; the annual capacity of dragline ESH 20.90 on excavation - 2800 thousand $\mathrm{m}^{3}$, and on re-excavation -3100 thousand $\mathrm{m}^{3}$. Planned volume of coal extraction at the site is 800 thous. tons.

Fig. 3 shows the dependence of the annual volume of coal output $\left(\mathrm{O}_{a}\right)$ on the height of the transportless overburden $\left(\mathrm{H}_{\mathrm{dd}}\right)$ and the width of the strip $\left(\mathrm{W}_{\mathrm{s}}\right)$. 


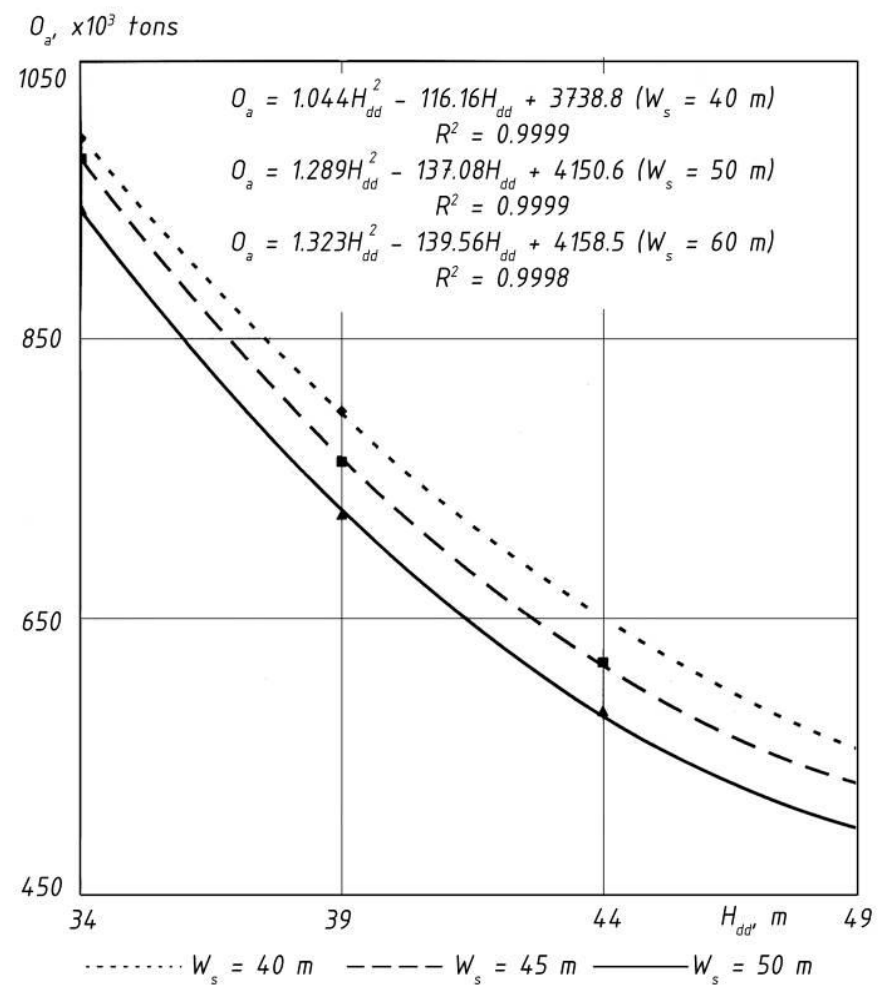

Fig. 3. Dependence of the annual volume of coal output $\left(\mathrm{O}_{\mathrm{a}}\right)$ on the height of the transportless overburden $\left(\mathrm{H}_{\mathrm{dd}}\right)$ and the width of the strip $\left(\mathrm{W}_{\mathrm{s}}\right)$.

From the graphs in Fig. 3 we can see that at the same thickness of the direct dumping overburden $\left(\mathrm{H}_{\mathrm{dd}}\right)$ the volume of extracted coal $\left(\mathrm{O}_{\mathrm{a}}\right)$ is the greatest at the minimum width of the strip, which is caused by the smallest value of re-excavation ratio (Fig. 2-a, b).

Therefore, for Kureinsky site the following main parameters of direct dumping scheme are recommended: the width of overburden strip is $40 \mathrm{~m}$; thickness of transportless overburden should be $39 \mathrm{~m}$.

Thus, the recommended basic parameters of direct dumping scheme provide fulfillment of the annual production plan at the site and the lowest unit costs for stripping.

\section{References}

1. M. Cehlár, P. Rybár, J. Mihók, J. Engel, Journal of Mining and Geotechnical Engineering, 1:8, 4 (2020)

2. M. Tyulenev, S. Markov, M. Cehlar, S. Zhironkin, M. Gasanov, Acta Montanistica Slovaca, 23:4, 368 (2018)

3. I. Vukotic, V. Kecojevic, W. Zhang, Q. Cai, S. Chen, Int J Mining Sci Tech, 23:6, 901 (2013)

4. S. Markov, J. Janočko, M. Tyulenev, Y. Litvin, E3S Web of Conferences, 105, 01021 (2019)

5. S. Markov, V. Martyanov, E. Preis, A. Abay, E3S Web of Conf., 21, 01021 (2017) 
6. A. Strelnikov, S. Markov, L. Rattmann, D. Weber, E3S Web of Conf., 41, 01003 (2018)

7. M. Tyulenev, S. Markov, A. Palamarchuk, T. Gvozdkova, J Mining Geotech Eng, 3(10), 18 (2020)

8. M. M. Bereznyak, A.V. Kalinin, V.G. Pronoza, Soviet Mining, 6:6, 638 (1970)

9. H. Mirabediny, A dragline simulation model for strip mine design and development (University of Wollongong, Wollongong, 1998)

10. A. V. Vaneev, J Mining Geotech Eng, 2, 13 (2018)

11. M. Mohammadi, P. Rai, S. Gupta, Acta Montranistica Slovaca, 21:1, 1 (2016)

12. M. Vaněk, G.F. Valverde, I. Černý, V. Hudeček, Acta Montanistica Slovaca, 25:2, 170 (2020)

13. M. Tyulenev, S. Zhironkin, E. Tyuleneva, A. Abay, S. Anyona, M. Hellmer, Coal International, 265(3), 30 (2017)

14. M. Tyulenev, Yu. Lesin, E. Tyuleneva, E. Murko, E3S Web of Conf., 15, 02003 (2017)

15. V. F. Kolesnikov, J. Janočko, J Mining Geotech Eng, 2:9, $42-74$ (2020)

16. S. Markov, M. Tyulenev, O. Litvin, E. Tyuleneva, E3S Web of Conf., 15, 01011 (2017)

17. P. Rai, Indian J Eng Material Sci, 11, 493 (2004)

18. M. Tyulenev, S. Markov, E. Makridin, Yu. Lesin, V. Gogolin, E3S Web of Conf., 105, 02022 (2019)

19. M. Andrejiova, A. Grincova, D. Marasova, P. Grendel, Acta Montanistica Slovaca, 20(1), 26 (2015)

20. Y. Lesin, V. Gogolin, E. Murko, S. Markov, J. Kretschmann, E3S Web of Conf., 41, 01039 (2018)

21. M. Grujic, D. Malindzak, D. Marasova, Tehnicki Vjesnik, 18:3, 453 (2011)

22. M. A. Tyulenev, S. O. Markov, M. A. Gasanov, S. A. Zhironkin, Geotech Geol Eng, 36:5, 2789 (2018)

23. K. Drebenshtedt, V. I. Golik, Yu. V. Dmitrak, Sustainable development of mountain territories, 10(1), 125 (2018)

24. A. Khoreshok, K. Ananiev, A. Ermakov, D. Kuziev, A. Babarykin, Acta Montanistica Slovaca, 25:1, 70 (2020)

25. A.B. Palamarchuk, A.V. Stukan, T.N. Gvozdkova, Journal of Mining and Geotechnical Engineering, 1:4, 50 (2019) 